\title{
MADRASAH
}

130 | P a g e

Jurnal Pendidikan dan Pembelajaran Dasar

p ISSN: 1979-5599 | e ISSN: 2502-194X

\section{IMPLEMENTASI METODE MIND MAPPING UNTUK MENINGKATKAN KEMAMPUAN MENULIS CERITA PADA SISWA KELAS IV SDN SUMURGUNG}

\author{
Enik Widarwati
}

Sekolah Dasar Negeri (SDN) Sumurgung Tuban, Indonesia

\begin{abstract}
Kemampuan dapat diidentifikasi sebagai kesanggupan, kecakapan, kekuatan, atau potensi diri sendiri. Kemampuan awal siswa merupakan prasarat yang diperlukan dalam mengikuti proses belajar mengajar selanjutnya. Proses pembelajaran dan pengambangan kemampuan awal siswa dapat menjadi titik tolak untuk membekali siswa agar dapat mengembangkan kemampuan baru. Sedangkan menulis cerita merupakan kegiatan menyampaikan pesan melalui media tulisan beserta tanda bacanya atau kegiatan merubah bunyi yang dapat di dengar menjadi kata-kata yang dapat dilihat. - Tujuan dari penelitian ini adalah untuk meningkatkan kemampuan menulis cerita melalui penggunaan metode peta pikiran Mind Mapping pada siswa kelas IV SDN Sumurgung tahun pelajaran 2008/2009. Variabel yang menjadi sasaran perubahan dalam penelitian tindakan kelas ini adalah kemampuan menulis cerita, sedangkan variabel tindakan yang digunakan dalam penelitian ini adalah metode peta pikiran Mind Mapping. Penelitian ini menggunakan penelitian tindakan (action research) sebanyak tiga putaran. Setiap putaran terdiri dari empat tahap yaitu: rancangan, kegiatan dan pengamatan, refleksi, dan refisi. Sasaran penelitian ini adalah siswa kelas IV SDN Sumurgung tahun pelajaran 2008/2009. Data yang diperoleh berupa hasil tes formatif, lembar observasi kegiatan belajar mengajar. Dari hasil analis didapatkan bahwa prestasi belajar siswa mengalami peningkatan dari siklus I sampai siklus III yaitu, siklus I $(65,22 \%)$, siklus II $(73,91 \%)$, siklus III $(91,30 \%)$ dengan nilai rata-rata siklus I $(63,87)$, siklus II $(74,35)$, dan siklus III $(80,43)$. Kesimpulan dari penelitian ini adalah metode Mind Mapping dapat berpengaruh positif terhadap kemampuan menulis cerita siswa kelas IV SDN Sumurgung tahun pelajaran 2008/2009, serta model pembelajaran ini dapat digunakan sebagai salah satu alternatif pembelajaran Bahasa Indonesia.
\end{abstract}

Keyword: Metode Mind Mapping; Bahasa Indonesia; Kemampuan Menulis Cerita;

Copyright (C) 2017 Madrasah Jurnal Pendidikan dan Pembelajaran Dasar. All Right Reserved

\section{A. PENDAHULUAN}

Dalam rangka meningkatkan kualitas hasil belajar Bahasa Indonesia yang lebih baik, dapat dimulai dengan memilih strategi belajar yang tepat. Menurut Iskandarwassid dan Dadang Sunendar (2009 : 168) agar tujuan pembelajaran dapat tercapai maksimal, maka diperlukan strategi pembelajaran yang tepat. Adakalanya tujuan pembelajaran tidak tercapai karena guru kurang mampu memilih strategi pembelajaran yang tepat untuk anak didiknya. Strategi pembelajaran yang baik bertumpu pada pemilihan pendekatan dan metode pembelajaran yang tepat. Metode mengajar merupakan cara yang digunakan guru dalam kegiatan pembelajaran dan juga merupakan usaha untuk mencapai tujuan pembelajaran. Kegiatan pembelajaran akan kurang berarti bila tidak ditunjang dengan metode yang tepat.

Vol. 9 No. 2, Juni 2017

Madrasah homepage: http://ejournal.uin-malang.ac.id/index.php/madrasah/index 
Prestasi dan motifasi belajar siswa terhadap suatu pelajaran menjadi kurang baik salah satu penyebabnya adalah penyampaian materi yang kurang menarik minat siswa, sehingga tujuan pembelajaran untuk melatih cara berfikir secara sistematis, logis, kritis, kreatif dan konsisten tidak tercapai secara maksimal.

Pada pembelajaran menulis cerita, sebelumnya peneliti telah menggunakan metode ceramah dan penugasan, namun hal tersebut masih belum memberikan hasil yang memuaskan dengan perolehan nilai siswa seperti pada grafik 1.1. di bawah ini.

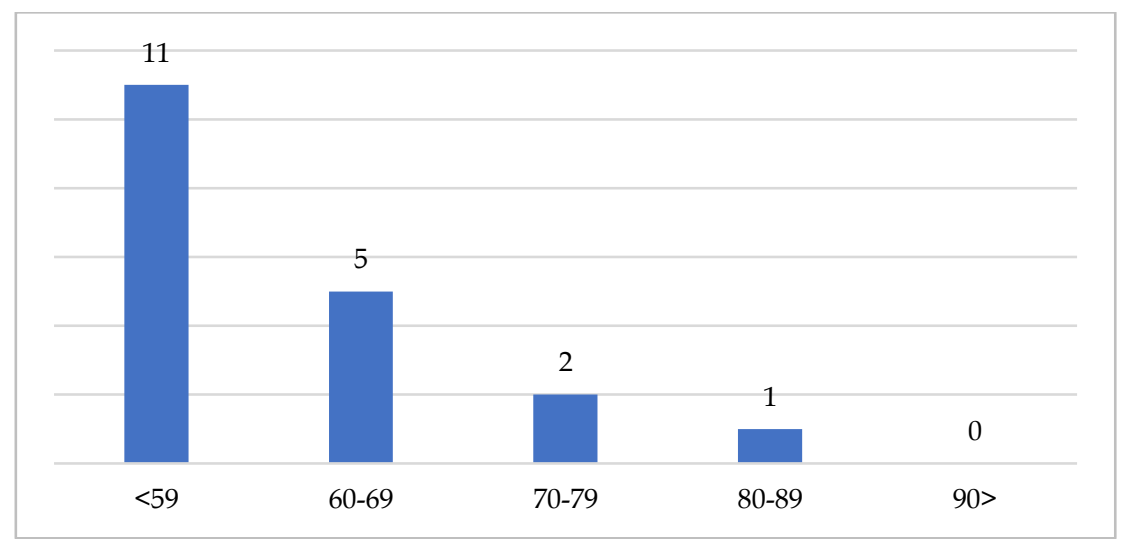

Grafik A.1 Data Awal Perolehan Nilai Siswa

Rendahnya kemampuan menulis cerita siswa kelas IV SDN Sumurgung disebabkan oleh beberapa faktor. Namun penyebab yang utama adalah karena siswa kurang mampu memiliki bayangan tentang hal-hal pokok yang akan mereka tulis dalam cerita. Siswa sering merasa bingung tentang bagaimana memulai cerita, apa yang akan ditulis selanjutnya, dan bagaimanakah akhirnya. Selain itu siswa kurang mampu menghubungkan ide-ide yang mereka miliki. Sebab itu dari data grafik 1.1 di atas dapat simpulkan bahwa ketuntasan siswa dalam pembelajaran bahasa masih rendah atau tidak signifikan kalau menggunakan metode ceramah dan tugas untuk meningkatkan kemampuan siswa dalam hal menulis cerita.

Untuk meningkatkan kualitas proses dan hasil dalam pembelajaran menulis cerita di SDN Sumurgung, penulis mencoba menerapkan pendekatan pembelajaran metode Mind Mapping. Pada dasarnya, metode Mind Mapping merupakan cara termudah untuk menempatkan informasi ke dalam otak dan mengambil informasi ke luar dari otak (Tony Buzan, 2008: 4). Sehingga dengan metode tersebut siswa akan mudah mencurahkan ide dan pengalaman yang telah dia miliki ke dalam cerita yang ingin mereka buat. Selain itu Mind Mapping juga merupakan alat yang dapat membantu otak berpikir secara teratur, dan mampu memetakan pikiran dalam bentuk simbol-simbol nyata. Sehingga dengan metode Mind Mapping siswa mudah dalam menyusun ide-ide dan pikiran pokok tentang cerita yang akan ditulisnya. Dengan demikian proses mencurahkan ide dan menghubungkan ide-ide dalam bentuk cerita akan lebih mudah.

Dengan menyadari gejala-gejala atau kenyataan tersebut di atas, maka dalam penelitian ini penulis mengambil judul "Implementasi Metode Mind Mapping untuk Meningkatkan Kemampuan Menulis Cerita Pada Siswa Kelas IV SDN Sumurgung Tahun Pelajaran 2008/2009."

Vol. 9 No. 2, Juni 2017

Madrasah homepage: http://ejournal.uin-malang.ac.id/index.php/madrasah/index 


\section{MADRASAH}

132 | P a ge

Jurnal Pendidikan dan Pembelajaran Dasar

p ISSN: 1979-5599 | e ISSN: 2502-194X

Rumusan masalah dalam penelitian ini yaitu: (1) 1. Apakah penggunaan metode Mind Mapping dapat meningkatkan kemampuan menulis cerita pada siswa kelas IV pada siswa kelas IV SDN Sumurgung tahun pelajaran 2008/2009?

Sesuai dengan permasalahan di atas, penelitian ini bertujuan untuk: meningkatkan kemampuan menulis cerita melalui penggunaan metode Mind Mapping pada siswa kelas IV SDN Sumurgung tahun pelajaran 2008/2009

Penelitian ini dapat memberikan manfaat bagi: (1) Sekolah sebagai penentu kebijakan dalam upaya meningkatkan prestasi belajar siswa khususnya pada mata pelajaran bahasa Indonesia; (2) Guru, sebagai bahan pertimbangan dalam menentukan metode pembelajaran yang dapat memberikan manfaat bagi siswa; (3) Siswa, dapat meningkatkan kemampuan menulis cerita pada pelajaran Bahasa Indonesia; (4) Meningkatkan belajar siswa pada pelajaran bahasa Indonesia; dan (5) Mengembangkan model pembelajaran yang sesuai.

Disebabkan keterbatasan waktu, maka diperlukan pembatasan masalah yang meliputi; (1) Penelitian ini hanya dikenakan pada siswa kelas IV SDN Sumurgung Tahun Pelajaran 2008/2009; (2) Penelitian ini dilakukan pada bulan Maret-Mei semester genap Tahun Pelajaran 2008/2009; dan (3) Materi yang disampaikan adalah pokok bahasan menulis cerita.

\section{B. LANDASAN TEORI}

\section{Hakikat Kemampuan Menulis Cerita}

Kemampuan dalam Kamus Besar Bahasa berasal dari kata "mampu" yang berarti bisa atau sanggup. Kemampuan dapat diidentifikasi sebagai kesanggupan, kecakapan, kekuatan, atau potensi diri sendiri. Kemampuan awal siswa merupakan prasarat yang diperlukan dalam mengikuti proses belajar mengajar selanjutnya. Proses pembelajaran dan pengambangan kemampuan awal siswa dapat menjadi titik tolak untuk membekali siswa agar dapat mengembangkan kemampuan baru.

Menurut Gagne dalam Ratna Willis Dahar (1989 : 134) "Penampilan-penampilan yang diamati sebagai hasil belajar disebut kemampuan-kemampuan, kemudian untuk mendapatkan pengetahuan dan kemampuan baru membutuhkan kemampuankemampuan tersebut."

Berdasarkan uraian di atas dapat disimpulkan bahwa kemampuan awal siswa merupakan kesanggupan dan pengetahuan yang dimiliki siswa pada awalnya yang diperlukan untuk memperoleh kemampuan dan pengetahuan yang lebih tinggi tingkatannya.

Menulis merupakan kegiatan menyampaikan pesan melalui media tulisan beserta tanda bacanya. Asul Wiyanto (2004: 1) mengungkapkan bahwa kata menulis mempunyai dua arti. Pertama, menulis merupakan kegiatan merubah bunyi yang dapat di dengar menjadi kata-kata yang dapat dilihat. Asul mencontohkan dengan bunyi "Buku" sebagai berikut:

"Bunyi itu menjadi lambang atau wakil benda berupa 'lembaran-lembaran kertas bertulis yang dijilid'. Kalau kita mengucapkan 'Buku', lembaran-lembaran kertas yang dijilid itu tidak keluar dari mulut kita. Akan tetapi, bersamaan dengan bunyi 'buku' itu pikiran kita membayangkan kertas yang dijilid itu. Jadi, bunyi 'Buku' sebagai lambang kitab meskipun tidak semua buku dapat disebut kitab.

Vol. 9 No. 2, Juni 2017

Madrasah homepage: http://ejournal.uin-malang.ac.id/index.php/madrasah/index 
Kedua, menulis menurut Asul (2004:2) adalah kegiatan mengungkapkan Gagasannya secara tertulis. Misalnya, bila seorang mahasiswa ingin mengupkapkan gagasannya tentang cara mengajarkan menulis cerita dengan metode yang tepat, maka dia menuliskannya dalam bentuk skripsi. Dengan begitu pembaca dapat menangkap gagasan mahasiswa tersebut dan meresponnya dengan kegiatan nyata. Dengan kata lain, menulis dalam arti yang kedua ini adalah penulis menuangkan gagasannya dalam bentuk tulisan dan pembaca menangkap gagasan penulis lewat membaca tulisan tersebut.

Mc Crimmon dalam St. Y Slamet (2008:141) menulis adalah kegiatan menggali ide dan gagasan tentang suatu hal, memilih dan memilah hal yang perlu ditulis, dan menentukan cara menuliskannya sehingga pembaca mudah memahami tulisan tersebut. Lebih lanjut lagi Agus Suriamiharja dkk (1996:2) mengungkapkan bahwa keterampilan menulis adalah kemampuan yang dimiliki penulis untuk melukiskan gagasannya dalam bentuk lambang grafis yang dipahami oleh pembaca. Dengan demikian kegiatan menulis dapat disamakan dengan kegiatan mengirimkan pesan dan kesan dari penulis kepada pembaca

Berdasarkan beberapa pendapat di atas maka dapat disimpulkan bahwa menulis adalah kegiatan untuk menyampaikan pesan, gagasan, atau ide seorang penulis kepada pembaca melalui media tulisan dengan memperhatikan cara menuliskannya sehingga pembaca mudah memahami maksud penulis.

\section{Tujuan dan Manfaat Menulis}

Hugo Hartig dalam Henry Guntur (1994:24) menyebutkan tujuan menulis ada 7 yaitu :

a. Assigmenment purpose (tujuan penugasan). Penulis tidak mempunyai tujuan yang timbul dari dalam hatinya. Dia menulis karena mendapatkan tugas atau perintah orang lain. Contohnya seorang siswa yang dihukum gurunya untuk menyalin sebuah kalimat sebanyak 100 kali.

b. Altruistic purpose (tujuan altruistik). Penulis bertujuan untuk menyenangkan para pembaca, menghibur, memahami perasaan pembaca. Penulis ingin karyanya dapat menyenangkan hidup pembaca. Contohnya adalah para penulis novel

c. Persuasive purpose (tujuan persuasif). Tulisan yang bertujuan untuk meyakinkan pembaca tentang kebenaran gagasan atau ide yang diutarakan oleh penulis.

d. Informational purpose (tujuan informasional atau penerangan). Tulisan yang bertujuan untuk memberi informasi atau keterangan yang diketahui penulis kepada para pembacanya. Contohnya adalah pemaparan suatu kasus yang dilakukan oleh para wartawan.

e. Self-expressive purpose ( tujuan pernyataan diri). Tulisan yang bertujuan untuk memperkenalkan, dan menyatakan diri penulis kepada para pembacanya.

f. Creative purpose (tujuan kreatif). Tujuan ini erat hubungannya dengan pernyataan diri. Tetapi keinginan "kreatif" disini melebihi pernyataan diri karena keinginan penulis untuk mencapai nilai-nilai artistik dan nilai-nilai seni yang tinggi. Contohnya penyair yang menulis puisi.

g. Problem-solving purpose (tujuan pemecahan masalah). Penulis ingin memecahkan masalah yang dihadapi oleh penulis itu sendiri. Penulis menjelaskan dengan cermat pemikiran, gagasan dan masahmasalahnya sendiri, agar dapat dimengerti dan diterima oleh pembaca. Contohnya adalah klarifikasi suatu masalah yang dilakukan oleh seseorang.

Vol. 9 No. 2, Juni 2017

Madrasah homepage: http://ejournal.uin-malang.ac.id/index.php/madrasah/index 


\section{MADRASAH}

134 | P a g e

Jurnal Pendidikan dan Pembelajaran Dasar p ISSN: 1979-5599 | e ISSN: 2502-194X

Dari tujuan-tujuan di atas dapat diketahui bahwa setiap tujuan menulis dapat mempengaruhi jenis tulisan yang dibuat. Tujuan-tujuan tersebut sebagai dasar penulis menciptakan karyanya. Dari sekian banyak tujuan menulis, tujuan yang paling umum dan mendasar adalah untuk menyampaikan maksud penulis kepada pembaca melalui media tulisan.

Kegiatan menulis mempunyai banyak manfaatnya bagi penulis maupun bagi orang lain yang membacanya. Seperti yang diungkapkan oleh Sabarti Akhaidah dkk dalam St. Y. Slamet (2008: 169) tentang manfaat menulis yaitu : (a) Dapat mengenali kemampuan dan potensi diri tentang permasalahan yang sedang ditulisnya; (b) Dapat mengembangkan dan menghubung-hubungkan beberapa gagasan atau pemikiran; (c) Dapat memperluas pemikiran dan serta wawasan baik dalam ilmu teoritis maupun terapan; (d) Dapat menjelaskan dan mempertegas masalah yang rumit atau kabur; (e) Dapat menilai pendapat sendiri secara objektif; (f) Dapat memotivasi diri sendiri untuk belajar, membaca, dan memperluas wawasannya; dan (g) Dapat membiasakan diri untuk berpikir dan berbahasa secara tertib.

Sedangkan manfaat menulis menurut Asul Wiyanto (2004: 6-7) bahwa salah satu manfaat menulis adalah akan mendorong seseorang menjadi lebih aktif, lebih kreatif, dan lebih cerdas. Hal ini dapat terjadi karena untuk membuat tulisan yang baik diperlukan penguasaan beberapa hal, seperti memilih, dan merangkai kata, menyusun paragraf sampai dalam mempertimbangkan isi tulisan yang santun.

Menyadari dari banyaknya manfaat menulis di atas, maka perlu adanya sikap aktif untuk meningkatkan kemampuan menulis setiap siswa Sekolah Dasar. Hal tersebut penting karena dengan menguasai keterampilan menulis, setiap siswa SD akan mempunyai bekal yang cukup untuk belajar lebih baik di jenjang pendidikan berikutnya.

\section{Jenis Tulisan atau Karangan}

Weayer dalam Henry Guntur (1994:28) mengungkapkan bahwa berdasarkan bentuknya tulisan atau wacana dapat dibagi menjadi 4 kelompok, yaitu: (a) Eksposisi yang mencakup definisi dan analisis; (b) Deskripsi yang mencakup deskripsi ekspositori dan deskripsi literer; (c) Narasi yang mencakup urutan waktu, konflik, motif, titik pandang, pusat minat; dan (d) Argumentasi yang mencakup induksi dan deduksi.

Agak berbeda, Henry Guntur (1994: 24) membagi tulisan atau wacana berdasarkan tujuan penulisannya menjadi 4 kelompok, yaitu: (a) Wacana informatif (informative discourse), yaitu tulisan yang bertujuan untuk mengajarkan atau memberitahukan sesuatu kepada para pembacanya; (b) Wacana persuasif (persuasive discourse), yaitu tulisan yang bertujuan untuk mempengaruhi atau mendesak; (c) Wacana literer atau kesusastraan (literary discourse), yaitu tulisan yang bertujuan untuk menghibur, menyenangkan para pembaca; dan (d) Wacana ekspresif (expressive discourse), yaitu tulisan yang menunjukkan perasaan dan emosi penulis yang kuat dan berapi-api.

Dari sekian banyak ragam atau bentuk tulisan yang ada, kemampuan menulis yang diharapkan dikuasai anak dan diusahakan untuk ditingkatkan dalam penelitian ini adalah kemampuan menulis cerita atau narasi. Karena dengan menguasai kemampuan menulis cerita, diharapkan siswa lebih mudah untuk mencurahkan ide, pengetahuan dan gagasannya sehingga akan memberikan hasil optimal pada setiap pembelajaran yang dilakukan.

Vol. 9 No. 2, Juni 2017

Madrasah homepage: http://ejournal.uin-malang.ac.id/index.php/madrasah/index 


\section{Tahapan Menulis Cerita}

Untuk membuat tulisan atau karangan cerita diperlukan tahapan-tahapan yang harus di lalui oleh seorang penulis. Tahapan tersebut akan membuat isi dari tulisan atau karangan menjadi lebih berkualitas. Menurut Sabarti Akhaidah (1994: 2) menyatakan bahwa kegiatan menulis merupakan suatu proses, yaitu proses penulisan. Dalam suatu proses tentunya terdapat tahap-tahap yang harus dilalui, tahapan dalam proses penulisan tersebut antara lain (1) tahap prapenulisan (2) tahap penulisan (3) tahap revisi. Ketiga tahap penulisan tersebut berbedaberdeda namun saling berkaitan erat. Ketiga tahap itu merupakan tahapan utama yang masih dapat dijabarkan lagi menjadi langkah-langkah yang nyata. Dalam tahap pra penulisan ditentukan hal-hal pokok yang akan mengarahkan penulis dalam seluruh kegiatan penulisan itu. Setelah ditentukan hal-hal yang akan dilakukan, maka rencana tersebut dilaksanakan dalam tahap penulisan. Dalam tahap ini penulis menngembangkan gagasannya dan menuangkannya dalam bentuk tulisan sehingga hasil akhirnya didapat draft yang pertama. Selanjutnya dalam tahap revisi penulis membaca lagi tulisannya untuk mencari kekurangan, kesalahan maupun kelebihan kata yang tidak diperlukan. Dalam tahap revisi ini penulis juga dapat mengubah pokok pikiran dan memperluasnya sehingga hasil akhir didapat tulisan yang sesuai dengan keinginan penulis. Dalam pelaksanaan proses penulisan ketiga tahap tersebut seringkali tidak dapat dipisahkan dengan jelas dan saling tumpang tindih. Namun, hal tersebut wajar karena seseorang dapat melakukan lebih dari satu proses yang berbeda untuk mendapatkan hasil tulisan yang optimal.

Dengan mengetahui tahap-tahap menulis yang benar maka seseorang akan lebih mudah menghasilkan tulisan yang bermutu. Begitu juga seorang guru, dengan memahami tahap-tahap tersebut maka guru akan lebih mudah untuk mengajarkan cara menulis cerita kepada anak didiknya. Dan seorang siswa yang mengerti tahap-tahap menulis yang benar maka tidak akan kesulitan lagi untuk mengungkapkan hasil pemikirannya dalam bentuk tulisan.

\section{Peran Guru dalam Proses Pembelajaran Menulis Cerita}

Menurut Moh. Uzer Usman (2005:7), tugas guru sebagai profesi meliputi mendidik, mengajar, dan melatih. Mendidik berarti meneruskan dan mengembangkan nilai-nilai hidup. Mengajar berarti meneruskan dan mengembangkan ilmu pegetahuan dan teknologi. Melatih berarti mengembangkan keterampilan-keterampilan pada siswa.

Proses belajar berhubungan dengan bagaimana seseorang melakukan suatu kegiatan jasmani dan rohani dalam rangka memperoleh pengetahuan baru. Soedomo Hadi (2005:23) mengemukakan bahwa tugas-tugas pendidik dikelompokkan menjadi 3, yaitu: (1) Tugas Educational (pendidik); (2) Tugas Instruksional; dan (3) Tugas Managerial.

Sedangkan menurut Adam dan Decey dalam Muhammad Uzer Usman (2005:9), menyatakan bahwa peranan dan kompetensi guru dalam proses pembelajaran meliputi beberapa hal, yaitu: (1) Guru sebagai demonstrator; (2) Guru sebagai pengelola kelas; (3) Guru sebagai mediator dan fasilitator; dan (4) Guru sebagai evaluator

Dari pendapat-pendapat di atas, dapat disimpulkan bahwa tugas guru adalah mendidik, mengajar, dan melatih siswa baik secara jasmani maupun rohani sehingga ilmu pengetahuan dapat diteruskan dan dikembangkan oleh generasi yang baru.

Gino (1995:36-39) mengungkapkan bahwa suatu proses pembelajaran dikatakan berhasil apabila tujuan yang telah ditentukan dalam proses pembelajaran yang dilakukan telah tercapai. Keberhasilan pencapaian tujuan tersebut dipengaruhi oleh beberapa faktor sebagai berikut:

Vol. 9 No. 2, Juni 2017

Madrasah homepage: http://ejournal.uin-malang.ac.id/index.php/madrasah/index 


\section{MADRASAH}

a. Minat belajar; Minat belajar berhubungan dengan kesediaan melakukan kegiatan belajar secara sungguh-sungguh. Minat belajar yang tinggi akan membuahkan hasil belajar yang baik.

b. Motivasi belajar; Motivasi belajar merupakan dorongan untuk terus melakukan proses belajar. Motivasi belajar ini dapat di peroleh dari diri sendiri maupun orang lain.

c. Bahan belajar; Bahan belajar adalah materi yang dipelajari oleh siswa tersebut. Bahan belajar untuk siswa SD disesuaikan dengan kondisi perkembangannya.

d. Alat bantu belajar; Alat bantu belajar ini mencakup beberapa hal, diantaranya adalah media belajar. Media menulis cerita dapat mengunakan gambar, rekaman suara, dan video.

e. Suasana belajar; Suasana belajar yang kondusif akan meningkatkan hasil belajar. Suasana belajar ini meliputi suasana lingkungan sekitar saat belajar dan suasana kelas atau proses pembelajaran yang berlangsung.

f. Kondisi siswa yang belajar; Kondisi siswa yang belajar meliputi kondisi jasmani dan rohani. Misalnya siswa akan belajar lebih baik jika dia dia tidak dalam kondisi sakit dan hatinya merasa senang.

g. Kemampuan guru; Kemampuan guru untuk menciptakan proses pembelajaran yang aktif dan menyenangkan dapat meningkatkan hasil belajar siswanya.

h. Metode pembelajaran; Metode pembelajaran yang tepat akan membuat proses pembelajaran berlangsung dengan baik yang berujung dengan meningkatnya hasil belajar.

\section{Evaluasi Pembelajaran Menulis Cerita}

Istilah evaluasi merupakan alih bahasa dari evaluation. Menurut Carl $\mathrm{H}$. Witherington dalam Zaenal Arifin (2009: 5) mengungkapkan "an evaluation is a declaration that something has or does not value" dari pendapat tersebut dapat diketahui bahwa dalam evaluasi nilai sangat penting dan kita dapat memberikan nilai yang tepat pada seseorang melalui evaluasi. Selanjutnya Guba dan Lincoln dalam Zaenal Arifin (2009:5) menyatakan bahwa evaluasi sebagai "a process for describing an evaluand and judging its merit and worth" yang berarti bahwa evaluasi adalah suatu proses umtuk menggambarkan peserta didik dan menimbangnya dari segi nilai dan arti. Definisi ini menegaskan bahwa evaluasi bukan hanya berkaitan dengan nilai tetapi juga arti atau makna.

Dari pendapat-pendapat di atas dapat disimpulkan bahwa evaluasi adalah suatu proses yang sistematis dan berkelanjutan untuk menentukan kualitas nilai dan arti dari sesuatu berdasarkan kriteria tertentu sehingga dapat diambil suatu keputusan. Kriteria dibutuhkan agar proses menilai lebih terarah dalam artian terdapat batasan hal-hal yang dinilai serta dapat menambah objetivitas proses menilai itu sendiri.

Burhan Nurgiantoro dalam Iskandarwassid (2009:250) berpendapat bahwa penelitian yang dilakukan terhadap karangan bahasa siswa biasanya bersifat holistis, impresif, dan selintas. Maksudnya adalah penilaiannya dilakukan dengan menyeluruh berdasarkan kesan yang diperoleh dari membaca karangan selintas. Lebih jauh lagi Iskandarwassid (2009:250) memberikan kriteria penilaian sebagai berikut: (a) Kualitas dan ruang lingkup isi; (b) Organisasi dan penyajian isi; (c) Komposisi; (d) Kohesi dan koherensi; (e) Gaya dan bentuk bahasa; (f) Mekanik: tata bahasa, ejaan, tanda baca; (g) Kerapian tulisan dan kebersihan; dan (8) Respon positif pengajar terhadap karya tulis.

Penerapan model penilaian analitis dengan kriteria di atas dapat dilakukan dengan mempergunakan skala, misalnya skala 1 sampai dengan 10 atau interval 1-5. Sedangkan

Vol. 9 No. 2, Juni 2017

Madrasah homepage: http://ejournal.uin-malang.ac.id/index.php/madrasah/index 
dari kedelapan kriteria tersebut dapat diambil sebagian sesuai dengan tingkat umur maupun kemampuan siswa dalam mengarang. Misalnya untuk siswa SMA dan Perguruan Tinggi dapat menggunakan seluruh kriteria tersebut, namun untuk siswa SD hanya menggunakan sebagian kriteria sesuai dengan kelasnya.

\section{Hakikat Metode Mind Mapping}

Mind Mapping pertama kali di kembangkan oleh Tony Buzan, seorang psikolog berkebangsaan Inggris. Menurut Bagus Taruno Legowo (2009:1) pada masa awal perkembangannya hingga sekarang, mind map banyak diaplikasikan di bidang pendidikan, seperti teknik mencatat, meringkas pelajaran sekolah, menulis artikel atau cerita dan buku. Namun dalam perkembangan berikutnya, mind map dapat diaplikasikan dalam berbagai bidang seperti bisnis, pemerintahan, manajemen, bahkan perencanaan pengembangan suatu usaha yang besar. Secara lebih lanjut Bagus Taruno Legowo (2009:1) mengungkapkan bahwa lebih dari 250 juta orang di dunia ini menggunakan Mind Mapping untuk membantu mempermudah hidupnya. Bahkan perusahaan-perusahaan besar dunia seperti IBM, Microsoft, Oracle, Boeing, British Petroleum, HSBC, dan Ideo sebagai perusahaan konsultan desain nokia menggunakan Mind Mapping untuk menunjang proses bisnis mereka menjadi lebih hebat.

Sebagai penemu dari metode ini, Tony Buzan (2008:4) mengungkapkan "Mind map adalah cara termudah untuk menempatkan informasi kedalam otak dan mengambil informasi keluar dari otak. Mind map adalah cara mencatat yang kreatif, efektif, dan secara harfiah akan memtekan pikiran kita. Mind map juga sangat sederhana".

Menurut Caroline Edward (2009:63) Mind map menjadi cara mencatat atau meringkas yang mengakomodir cara kerja otak secara natural, sehingga Mind map adalah cara yang paling efektif untuk meningkatkan prestasi anak. Mind map adalah salah satu system yang menggunakan prinsip manajemen seluruh potensi otak sehingga fungsi belahan otak kiri dan otak kanan dapat dioptimalkan, yang kemudian dalam aplikasinya sangat membantu memahami masalah dengan cepat karena telah terpetakan.

Mind map merupakan pengejawantahan dari seluruh ide untuk ditranformasikan dalam bentuk gambar dan simbol. Dalam pembuatannya gagasan utama diletakkan di tengah-tengah halaman dan sering dilengkapi dengan lingkaran, persegi, atau bentuk lain. Dari gagasan utama, ditambahkan cabang-cabang untuk setiap komponen yang mengiringi gagasan utama tersebut. Jumlahnya bervariasi tergantung dari jumlah gagasan. Tiap-tiap cabang dikembangkan lagi secara detail dengan menuliskan kata kunci atau frase dan dapat pula berupa singkatan. Dengan begitu keterhubungan antar ide dan hal-hal yang terkait dengan ide tersebut akan terlihat.

Proses penggambaran ide ini sama halnya dengan otak manusia. Otak manusia tersusun dari bermilyar-milyar neuron yang saling berhubungan. Neuron tersebut mempunyai inti di tengah dan mempunyai serabut-serabut yang terjuntai di setiap sisinya yang menghubungkan neuron satu dengan yang lain. Melalui serabut-serabut tersebut pesan, kesan hasil dari pengindraan maupun reaksi dari pengindraan disalurkan ke dalam dan keluar dari otak.

Tony Buzan (2008:8) mengungkapkan bahwa symbol dan gambar seringkali lebih berdaya untuk mengungkapkan pikiran maupun mengingat suatu hal. Karena menurutnya "otak memiliki kemampuan alami untuk pengenalan visual, bahkan sebenarnya pengenalan yang sempurna". Oleh karena itu, simbol-simbol dan ilustrasiilustrasi dapat ditambahkan pada Mind map yang dibuat untuk menambatkan ingatan yang lebih baik. Selain itu Mind map yang baik dibuat dengan mengkombinasikan beberapa

Vol. 9 No. 2, Juni 2017

Madrasah homepage: http://ejournal.uin-malang.ac.id/index.php/madrasah/index 


\section{MADRASAH}

warna sehingga terkesan berwarna-warni dan tidak monoton. Menurut Sutanto Windura (2008:21) otak lebih menyukai sesuatu yang berwarna-warni. Dengan adanya kombinasi warna tersebut maka otak tidak akan merasa bosan. Sehingga jika Mind map yang berwarni diterapkan dalam pembelajaran maka anak akan lebih antusias dan senang saat belajar (Learning is Fun).

Menurut Tony Buzan (2008:9) pada jaman dahulu para jenius kreatif telah menggunakan bahasa gambar untuk menyusun, mengembangkan, dan mengingat pikiran mereka. Sebagai contoh, Leonardo da Vinci. Leonardo menggunakan gambar, diagram, simbol, dan ilustrasi sebagai cara termurni untuk menangkap pikiran-pikiran yang bermunculan di otaknya dan mencurahkannya di kertas. Baginya, bahasa kata-kata berada di tempat kedua sesudah bahasa gambar dan digunakan untuk memberi label, menunjukkan atau menjelaskan pikiran dan penemuan kreatifnya. Gambar-gambar membantu Leonardo menjelajah pikirannya dalam berbagai bidang, seni, ilmu faal, permesinan, akuanautik, dan biologi. Contoh lain adalah Richard Feynman, fisikawan pemenang Hadiah Nobel, ketika masih muda menyadari bahwa imajinasi dan visualisasi adalah bagian terpenting dari proses pemikiran kreatif. Dengan begitu ia memainkan permainan-permainan imajinasi dan belajar menggambar. Ia menempatkan seluruh teori kuantum elektrodinamik ke bentuk visual dan diagramatik yang baru. Ini menjurus ke pengembangan diagram Feynman. Diagram Feynmen menggambarkan representasi dari interaksi partikel, yang sekarang digunakan murid di seluruh dunia untuk membantu mereka memahami, mengingat, dan menciptakan ide-ide dalam realisme fisika dan ilmu umum.

\section{Manfaat Mind Mapping}

Peta pikiran memberikan banyak manfaat. Peta pikiran, memberikan pandangan menyeluruh pada setiap aspek permasalahan dan memberikan sudut pandang pada area yang luas, memungkinkan kita merencanakan rute atau membuat pilihan-pilihan dan mengetahui ke mana kita akan pergi dan di mana kita berada. Keuntungan lain yaitu mengumpulkan sejumlah besar data di suatu tempat, mendorong pemecahan masalah dengan membiarkan kita melihat jalan-jalan terobosan kreatif baru, merupakan sesuatu yang menyenangkan untuk dipandang, dibaca, direnungkan dan diingat.

Untuk anak-anak, peta pikiran memiliki manfaat, yaitu: membantu dalam mengingat, mendapatkan ide, menghemat waktu, berkonsentrasi, mendapatkan nilai yang lebih bagus, mengatur pikiran dan hobi, media bermain, bersenang-senang dalam menuangkan imajinasi yang tentunya memunculkan kreativitas.

\section{Langkah-langkah Pembelajaran Menulis Cerita dengan Metode Mind Mapping}

Pelaksanaan pembelajaran menulis cerita pada mata pelajaran bahasa Indonesia kelas IV dengan metode Mind Mapping dapat dijabarkan dengan langkah-langkah sebagai berikut.

a. Pertama-tama guru bersama siswa memilih ide/gagasan cerita kemudian menuliskannya di tengah selembar kertas kosong.

b. Siswa mengembangkan gagasan pokok dengan menuliskan kata-kata kunci pada cabang-cabang yang meliputi gagasan pokok tersebut sehingga menjadi sebuah Mind Map kerangka karangan.

c. Bila diperlukan, guru membantu siswa untuk mengembangkan gagasan pokok tersebut dengan menuliskan kata tanya kapan, dimana, siapa, mengapa, dan bagaimana.

Vol. 9 No. 2, Juni 2017

Madrasah homepage: http://ejournal.uin-malang.ac.id/index.php/madrasah/index 
d. Siswa mengembangkan Mind Map kerangka karangannya dengan menambahkan keterangan lagi disetiap cabang yang telah dibuat sebelumnya.

e. Siswa memberikan warna, simbol dan gambar yang menarik pada Mind Map kerangka karangannya.

f. Setelah siswa selesai membuat Mind Map kerangka karangannya, baru diberikan tugas untuk membuat cerita berdasarkan Mind Map kerangka karangan yang telah dibuat.

g. Ide yang muncul di tengah aktivitas menulis dapat dituangkan dalam cabangcabang atau ranting mana pun dalam peta pikiran untuk selanjutnya ditambahkan dalam karangan cerita.

Berikut ini adalah contoh Mind Mapping kerangkan karangan sebuah cerita yang ditampilkan pada gambar B.1.

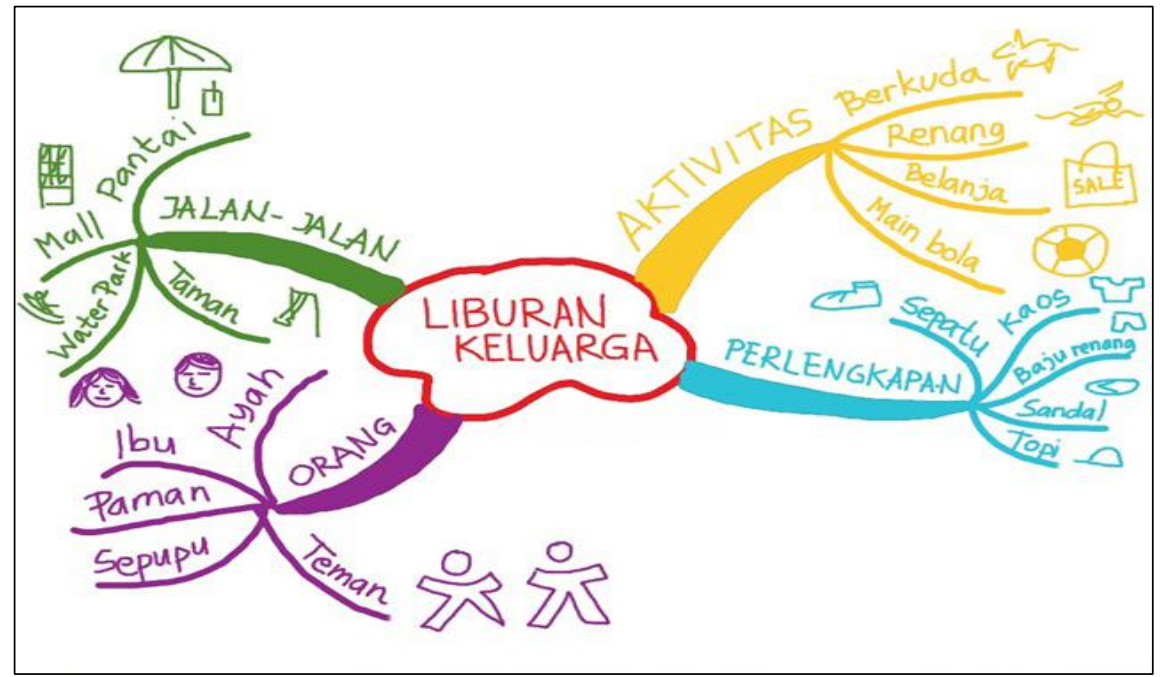

Gambar B.1 Contoh Mind Mapping

\section{METODOLOGI PENELITIAN}

Penelitian ini merupakan penelitian tindakan (action research), karena penelitian dilakukan untuk memecahkan masalah pembelajaran di kelas. Penelitian ini juga termasuk penelitian deskriptif, sebab menggambarkan bagaimana suatu teknik pembelajaran diterapkan dan bagaimana hasil yang diinginkan dapat dicapai.

Tempat penelitian adalah tempat yang digunakan dalam melakukan penelitian untuk memperoleh data yang diinginkan. Penelitian ini bertempat di SDN Sumurgung Kecamatan Montong Kabupaten Tuban. Waktu penelitian adalah waktu berlangsungnya penelitian atau saat penelitian ini dilangsungkan. Penelitian ini dilaksanakan pada bulan Maret-Mei 2009 Sedangkan subyek penelitian adalah siswa-siswi kelas IV SDN Sumurgung tahun pelajaran 2008/2009 pokok bahasan menulis cerita.

\section{Desain Penelitian}

Penelitian ini menggunakan model penelitian tindakan dari Kemmis dan Taggart (dalam Sugiarti, 1997:6), yaitu berbentuk spiral dari sklus yang satu ke siklus yang berikutnya. Setiap siklus meliputi planning (rencana), action (tindakan), observation (pengamatan), dan reflection (refleksi). Langkah pada siklus berikutnya adalah perncanaan yang sudah direvisi, tindakan, pengamatan, dan refleksi. Sebelum masuk pada siklus I dan II dilakukan tindakan pendahuluan yang berupa identifikasi permasalahan.

Vol. 9 No. 2, Juni 2017

Madrasah homepage: http://ejournal.uin-malang.ac.id/index.php/madrasah/index 


\section{MADRASAH}

140 | P a g e

Jurnal Pendidikan dan Pembelajaran Dasar

p ISSN: 1979-5599 | e ISSN: 2502-194X

Data diperoleh melalui observasi, pengolahan metode pembelajaran, observasi aktivitas guru dan siswa, serta tes formatif. Instrument yang digunakan meliputi: silabus, RPP, lembar kegiatan siswa, lembar observasi pengolahan model pembelajaran mind mapping, lembar observasi aktivitas guru dan siswa, serta tes formatif yang disusun berdasarkan tujuan pembelajaran dengan analisis butir soal tes yang telah diuji validitas dan reliabilitas tiap soal, serta uji taraf kesukaran dan daya pembeda. Teknik analisis data yang digunakan yaitu teknik analisis deskriptif kualitatif.

Variabel penelitian tindakan kelas ini adalah : (1) Variabel bebas adalah variabel yang mempengaruhi perubahan pada variabel terikat yaitu model mind mapping; dan (2) Variabel terikat adalah variabel yang dipengaruhi oleh variabel bebas yaitu tingkat penguasaan materi pokok bahasan menulis cerita.

Untuk menganalisis tingkat keberhasilan atau persentase keberhasilan siswa setelah proses belajar mengajar setiap putarannya dilakukan dengan cara memberikan evaluasi berupa soal tes tertulis pada setiap akhir putaran. Analisis ini dihitung dengan menggunakan statistik sederhana yaitu:

a. Untuk menilai ulangan atau tes formatif

Peneliti melakukan penjumlahan nilai yang diperoleh siswa, yang selanjutnya dibagi dengan jumlah siswa yang ada di kelas tersebut sehingga diperoleh rata-rata tes formatif dapat dirumuskan:

$$
\begin{aligned}
\bar{X}=\frac{\sum X}{\sum N} \text { Dengan }: \bar{X} & =\text { Nilai rata-rata } \Sigma \mathrm{X}=\text { Jumlah semua nilai siswa } \\
\Sigma \mathrm{N} & =\text { Jumlah siswa }
\end{aligned}
$$

b. Untuk ketuntasan belajar

Setiap siswa dikatakan tuntas belajarnya (ketuntasan individu) jika proporsi jawaban benar siswa $\geq 65 \%$, dan suatu kelas dikatakan tuntas belajarnya (ketuntasan klasikal) jika dalam kelas tersebut terdapat $\geq 85 \%$ siswa yang telah tuntas belajarnya (Depdikbud dalam Trianto, 2010: 241).

Lebih lanjut Trianto (2010: 241) bahwa ketentuan KTSP penentuan ketuntasan belajar ditentukan sendiri oleh masing-masing sekolah yang dikenal dengan istilah kriteria ketuntasan minimal, dengan berpedoman pada tiga pertimbangan, yaitu: kemampuan setiap peserta didik berbeda-beda; fasilitas (sarana) setiap sekolah berbeda; dan daya dukung setiap sekolah berbeda. Maka dalam penelitian ini, sesuai dengan KKM di sekolah tempat peneliti melakukan penelitian, maka ketuntasan individual adalah 65 dan ketuntasan secara klasikal adalah $85 \%$.

Untuk menghitung persentase ketuntasan belajar digunakan rumus sebagai berikut:

$$
P=\frac{\sum \text { Siswa.yang.tuntas.belajar }}{\sum \text { Siswa }} \times 100 \%
$$

c. Untuk lembar observasi

1) Lembar observasi pengelola model pembelajaran mind mapping. Untuk menghitung lembar observasi pengelolaan model pembelajaran mind mapping digunakan rumus sebagai berikut:

$$
\overline{\mathrm{X}}=\frac{P 1+P 2}{2} \quad \text { Dimana } \mathrm{P} 1=\text { Pengamat } 1 \text { dan } \quad \mathrm{P} 2=\text { Pengamat } 2
$$

Vol. 9 No. 2, Juni 2017

Madrasah homepage: http://ejournal.uin-malang.ac.id/index.php/madrasah/index 
2) Lembar observasi aktifitas guru dan siswa. Untuk menghitung lembar observasi aktifitas guru dan siswa digunakan rumus sebagai berikut:

$$
\%=\frac{\bar{x}}{\Sigma x} \times 100 \% \text { dengan } X=\frac{\text { Jumah.hasil.pengama } \tan }{\text { Jumlah.pengama } \tan }=\frac{P 1+P 2}{2}
$$

$$
\begin{aligned}
& \text { Dimana: } \quad \frac{\%}{=} \quad=\text { Presentase pengamatan } \quad \bar{X}=\text { Rata-rata } \\
& \sum \overline{\mathrm{x}} \quad=\text { Jumlah rata-rata } \\
& \text { P1 = Pengamat } 1 \quad \text { P2 = Pengamat } 2
\end{aligned}
$$

\section{HASIL PENELITIAN \& PEMBAHASAN}

1. Hasil Analisis Item Butir Soal

Validitas butir soal dimaksudkan untuk mengetahui kelayakan tes sehingga dapat digunakan sebagai instrument dalam penelitian ini. Dari perhitungan 20 soal diperoleh 7 soal tidak valid dan 13 soal valid. Hasil dari validitas soal-soal dirangkum dalam tabel di bawah ini.

Tabel D.1 Soal Valid dan Tidak Valid Tes Formatif Siswa

\begin{tabular}{|cc|}
\hline Soal Tidak Valid & Soal Valid \\
\hline $1,2,5,6,8,10,13$ & $3,4,7,9,11,12,14,15,16,17,18,19,20$ \\
\hline
\end{tabular}

Soal-soal yang telah memenuhi syarat validitas diuji reliabilitasnya. Dari hasil perhitungan diperoleh koefisien reliabilitas $r_{11}$ sebesar 0,767 . Harga ini lebih besar dari harga $r$ product moment. Untuk jumlah siswa $(N=19)$ dengan $r(95 \%)=0,444$. Dengan demikian soal-soal tes yang digunakan telah memenuhi syarat reliabilitas. Taraf kesukaran digunakan untuk mengetahui tingkat kesukaran soal. Hasil analisis menunjukkan dari 20 soal yang diuji terdapat: (a) 4 soal mudah, (b) 12 soal sedang, dan (c) 4 soal sukar. Analisis daya pembeda dilakukan untuk mengetahui kemampuan soal dalam membedakan siswa yang berkemampuan tinggi dengan siswa yang berkemampuan rendah. Dari hasil analisis daya pembeda diperoleh soal yang berkriteria jelek sebanyak 4 soal, berkriteria cukup 12 soal, berkriteria baik 4 soal. Dengan demikian soal-soal tes yang digunakan telah memenuhi syara-syarat validitas, reliabilitas, taraf kesukaran, dan daya pembeda.

\section{Hasil Pengamatan Guru dan Siswa}

Berdasarkan pengamatan dan hasil catatan terhadap proses pembelajaran dan prestasi belajar tentang penggelolaan pembelajaran yang sudah di lakukan dapat di gambarkan seperti pada grafik D.1.

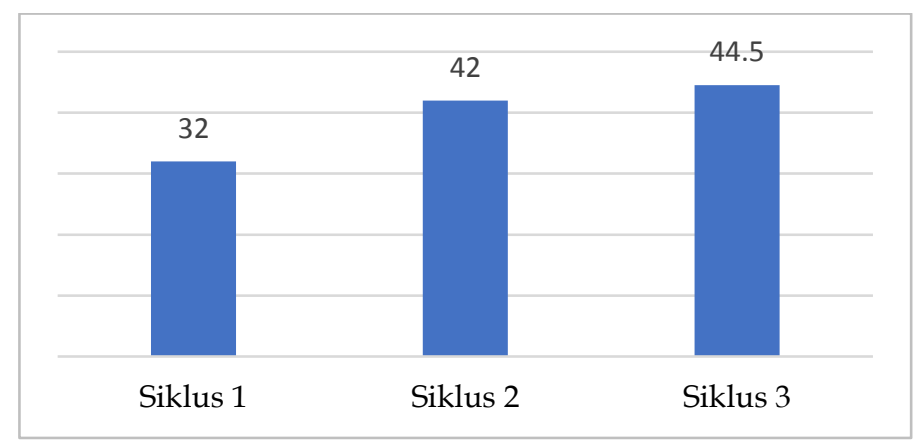

Grafik D.1 Rata-rata Hasil Pengelolaan Pembelajaran Tiap Siklus

Vol. 9 No. 2, Juni 2017

Madrasah homepage: http://ejournal.uin-malang.ac.id/index.php/madrasah/index 
Berdasarkan grafik di atas terlihat bahwa aktivitas pengelolaan pembelajaran per siklus mengalami peningkatan yang signifikan dalam implementasinya. Secara detail hasil pengamatan pengelolaan pembelajaran dapat dipaparkan sebagai berikut:

Aspek-aspek yang mendapatkan kriteria kurang baik pada pelaksanaan siklus I adalah memotivasi siswa, menyampaikan tujuan pembelajran, pengelolaan waktu, dan siswa antusias. Keempat aspek yang mendapat nilai kurang baik di atas, merupakan suatu kelemahan yang terjadi pada siklus I dan akan dijadikan bahan kajian untuk refleksi dan revisi yang akan dilakukan pada siklus II.

Sedangkan pelaksanaan pada siklus II yang dilaksanakn oleh guru dengan menerapkan metode pembelajaran Mind Mapping mendapatkan penilaian yang cukup baik dari pengamat. Maksudnya dari seluruh penilaian tidak terdapat nilai kurang. Namun demikian penilaian tesebut belum merupakan hasil yang optimal, untuk itu ada beberapa aspek yang perlu mendapatkan perhatian untuk penyempurnaan penerapan pembelajaran selanjutnya. Aspek-aspek tersebut adalah memotivasi siswa, membimbing siswa merumuskan kesimpulan/menemukan konsep, dan pengelolaan waktu. Dengan penyempurnaan aspek-aspek I dalam penerapan metode pembelajaran Mind Mapping diharapkan siswa dapat menyimpulkan apa yang telah mereka pelajari dan mengemukakan pendapatnya sehingga mereka akan lebih memahami tentang apa ynag telah mereka lakukan.

Pelaksanaan siklus III dari yang dilaksanakan oleh guru dengan menerapkan metode pembelajaran Mind Mapping mendapatkan penilaian cukup baik dari pengamat adalah memotivasi siswa, membimbing siswa merumuskan kesimpulan/menemukan konsep, dan pengelolaan waktu. Penyempurnaan aspek-aspek di atas dalam menerapkan metode pembelajaran Mind Mapping diharapkan dapat berhasil semaksimal mungkin.

\section{Hasil Nilai Tes Formatif Siswa}

Data nilai tes formatif siswa kelas IV SDN Sumurgung pada pembelajaran menulis cerita seperti pada tabel D.2.

Tabel D.2 Nilai Tes Formatif Tiap Siklus

\begin{tabular}{|ccccccc|}
\hline \multirow{2}{*}{$\begin{array}{c}\text { No Urut } \\
\text { Responden }\end{array}$} & \multicolumn{2}{c}{ Siklus I } & \multicolumn{2}{c}{ Siklus II } & \multicolumn{2}{c|}{ Siklus III } \\
\cline { 2 - 7 } & Skor & Ket & Skor & Ket & Skor & Ket \\
\hline 1 & 40 & TT & 50 & TT & 60 & TT \\
\hline 2 & 50 & TT & 60 & TT & 70 & $\mathrm{~T}$ \\
\hline 3 & 78 & $\mathrm{~T}$ & 80 & $\mathrm{~T}$ & 85 & $\mathrm{~T}$ \\
\hline 4 & 80 & $\mathrm{~T}$ & 85 & $\mathrm{~T}$ & 90 & $\mathrm{~T}$ \\
\hline 5 & 70 & $\mathrm{~T}$ & 80 & $\mathrm{~T}$ & 80 & $\mathrm{~T}$ \\
\hline 6 & 45 & $\mathrm{TT}$ & 60 & $\mathrm{TT}$ & 75 & $\mathrm{~T}$ \\
\hline 7 & 76 & $\mathrm{~T}$ & 80 & $\mathrm{~T}$ & 85 & $\mathrm{~T}$ \\
\hline 8 & 60 & $\mathrm{TT}$ & 75 & $\mathrm{~T}$ & 75 & $\mathrm{~T}$ \\
\hline 9 & 75 & $\mathrm{~T}$ & 85 & $\mathrm{~T}$ & 90 & $\mathrm{~T}$ \\
\hline 10 & 80 & $\mathrm{~T}$ & 90 & $\mathrm{~T}$ & 95 & $\mathrm{~T}$ \\
\hline 11 & 45 & $\mathrm{TT}$ & 75 & $\mathrm{~T}$ & 80 & $\mathrm{~T}$ \\
\hline 12 & 40 & $\mathrm{TT}$ & 60 & $\mathrm{TT}$ & 75 & $\mathrm{~T}$ \\
\hline 13 & 75 & $\mathrm{~T}$ & 80 & $\mathrm{~T}$ & 85 & $\mathrm{~T}$ \\
\hline 14 & 70 & $\mathrm{~T}$ & 75 & $\mathrm{~T}$ & 85 & $\mathrm{~T}$ \\
\hline 15 & 70 & $\mathrm{~T}$ & 80 & $\mathrm{~T}$ & 80 & $\mathrm{~T}$ \\
\hline 16 & 65 & $\mathrm{~T}$ & 75 & $\mathrm{~T}$ & 80 & $\mathrm{~T}$ \\
\hline
\end{tabular}

Vol. 9 No. 2, Juni 2017

Madrasah homepage: http://ejournal.uin-malang.ac.id/index.php/madrasah/index 


\begin{tabular}{|c|c|c|c|c|c|c|}
\hline \multirow{2}{*}{$\begin{array}{c}\text { No Urut } \\
\text { Responden }\end{array}$} & \multicolumn{2}{|c|}{ Siklus I } & \multicolumn{2}{|c|}{ Siklus II } & \multicolumn{2}{|c|}{ Siklus III } \\
\hline & Skor & Ket & Skor & Ket & Skor & Ket \\
\hline 17 & 45 & TT & 60 & TT & 75 & $\mathrm{~T}$ \\
\hline 18 & 70 & $\mathrm{~T}$ & 75 & $\mathrm{~T}$ & 80 & $\mathrm{~T}$ \\
\hline 19 & 70 & $\mathrm{~T}$ & 85 & $\mathrm{~T}$ & 90 & $\mathrm{~T}$ \\
\hline 20 & 75 & $\mathrm{~T}$ & 85 & $\mathrm{~T}$ & 90 & $\mathrm{~T}$ \\
\hline 21 & 70 & $\mathrm{~T}$ & 80 & $\mathrm{~T}$ & 80 & $\mathrm{~T}$ \\
\hline 22 & 75 & $\mathrm{~T}$ & 80 & $\mathrm{~T}$ & 85 & $\mathrm{~T}$ \\
\hline 23 & 45 & TT & 55 & TT & 60 & TT \\
\hline Jumlah Skor & 1288 & - & 1391 & - & 1457 & - \\
\hline Skor Ideal & 2300 & - & 2300 & - & 2300 & - \\
\hline \multicolumn{2}{|c|}{ Rata - Rata Skor Tercapai } & 63.87 & \multicolumn{2}{|c|}{73.21} & \multicolumn{2}{|c|}{76.68} \\
\hline \multicolumn{2}{|c|}{ Jumlah Siswa Tuntas } & 15 & \multicolumn{2}{|c|}{17} & \multicolumn{2}{|c|}{21} \\
\hline \multicolumn{2}{|c|}{ Jumlah Siswa Tidak Tuntas } & 8 & \multicolumn{2}{|c|}{6} & \multicolumn{2}{|c|}{2} \\
\hline \multicolumn{2}{|c|}{ Ketuntansan Klasikal } & TT & \multicolumn{2}{|c|}{ TT } & \multicolumn{2}{|c|}{$\mathrm{T}$} \\
\hline \multicolumn{2}{|c|}{$\begin{array}{l}\text { Persentase Ketuntasan } \\
\text { Belajar }\end{array}$} & 65,22 & \multicolumn{2}{|c|}{73,91} & \multicolumn{2}{|c|}{91,30} \\
\hline
\end{tabular}

Dari tabel di atas dapat dijelaskan bahwa dengan menerapkan metode pembelajaran Mind Mapping diperoleh nilai rata-rata prestasi belajar siswa adalah 63,87 dan ketuntasan belajar mencapai 65,22\% atau ada 15 siswa dari 23 siswa sudah tuntas belajar. Hasil tersebut menunjukkan bahwa pada siklus I secara klasikal siswa belum tuntas belajar, karena siswa yang memperoleh nilai $\geq 65$ hanya sebesar $65,22 \%$ lebih kecil dari persentase ketuntasan yang dikehendaki yaitu sebesar $85 \%$. Hal ini disebabkan karena siswa masih merasa baru dan belum mengerti apa yang dimaksudkan dan digunakan guru dengan menerapkan metode pembelajaran Mind Mapping.

Lebih lanjut dijelaskan dari tabel di atas bahwa pelaksanaan siklus II diperoleh nilai rata-rata prestasi belajar siswa adalah 74,35 dan ketuntasan belajar mencapai $76.91 \%$ atau ada 17 siswa dari 23 siswa sudah tuntas belajar. Hasil ini menunjukkan bahwa pada siklus II ini ketuntasan belajar secara klasikal telah mengalami peningkatan sedikit lebih baik dari siklus I. Adanya peningkatan hasil belajar siswa ini karena setelah guru menginformasikan bahwa setiap akhir pelajaran akan selalu diadakan tes sehingga pada pertemuan berikutnya siswa lebih termotivasi untuk belajar. Selain itu siswa juga sudah mulai mengerti apa yang dimaksudkan dan diinginkan guru dengan menerapkan metode pembelajaran Mind Mapping.

Sedangkan pada siklus III berdasarkan tabel di atas diperoleh nilai rata-rata tes formatif sebesar 80,43 dan dari 23 siswa yang telah tuntas sebanyak 21 siswa dan 2 siswa belum mencapai ketuntasan belajar. Maka secara klasikal ketuntasan belajar yang telah tercapai sebesar 91,30\% (termasuk kategori tuntas). Hasil pada siklus III ini mengalami peningkatan lebih baik dari siklus II. Adanya peningkatan hasil belajar pada siklus III ini dipengaruhi oleh adanya peningkatan kemampuan guru dalam menerapkan metode pembelajaran Mind Mapping membuat siswa menjadi lebih terbiasa dengan pembelajaran seperti ini sehingga siswa lebih mudah dalam memahami materi yang telah diberikan.

\section{Refleksi}

Dalam pelaksanaan kegiatan belajar mengajar diperoleh informasi dari hasil pengamatan dan penilaian hasil menulis cerita yang dikumpulkan untuk dianalisis dan direfleksi. Hal ini dilakukan sebagai pedoman atau acuan pengambilan langkah pada tahapan-tahapan tiap siklus. Dari hasil analisis dan refleksi pelaksanaan siklus I dan II

Vol. 9 No. 2, Juni 2017

Madrasah homepage: http://ejournal.uin-malang.ac.id/index.php/madrasah/index 


\section{MADRASAH}

$144 \mid \mathrm{P}$ a g e

Jurnal Pendidikan dan Pembelajaran Dasar p ISSN: 1979-5599 | e ISSN: 2502-194X

dapat disimpulkan bahwa proses pembelajaran yang dilakukan belum menunjukkan perubahan atau peningkatan secara signifikan, ditemukan beberapa permasalahan dan solusinya, sebagai berikut:

a. Sebagian besar siswa belum mampu mengerjakan soal tes evaluasi secara optimal, baik soal individu maupun kelompok. Hal ini dikarenakan guru belum dapat menyampaikan materi secara jelas terutama materi tentang langkah-langkah membuat cerita melalui peta pikiran (Mind Mapping). Selain itu kesulitan siswa untuk menyelesaikan tugas atau soal tes juga dipengaruhi oleh perintah dalam lembar kerja/evaluasi yang diberikan oleh guru kurang jelas bagi siswa. Dari permasalahan tersebut, maka pada siklus berikutnya guru mengulangi kembali materi mengenai langkah-langkah menulis cerita menggunakan metode Mind Mapping dengan jelas dan tepat agar semua siswa dapat memahami materi yang disampaikan dan membuat lembar kerja siswa menjadi jelas.

b. Keaktifan siswa di dalam pembelajaran masih kurang baik, respon siswa terhadap pertanyaan yang diberikan guru masih rendah. Hal ini disebabkan guru belum memahami siswa dan kelas sehingga guru kurang mampu dalam mengelola kelas dan memberikan motivasi. Untuk itu pada pembelajaran berikutnya, guru perlu meningkatkan pengelolaan kelas, memberikan apersepsi dan motivasi yang tepat pada awal pelajaran kepada siswa agar siswa lebih antusias dalam mengikuti pembelajaran.

c. Kemampuan siswa melakukan diskusi dalam pembelajaran masih dalam kategori kurang, pada saat berdiskusi banyak siswa yang masih takut untuk mengemukakan pendapat atau ide. Dari permasalahan tersebut, pada pembelajaran berikutnya guru memberikan motivasi berupa penghargaan baik secara verbal maupun non verbal kepada siswa agar mereka lebih berani lagi dalam menyampaikan pendapat.

d. Diskusi kelompok berjalan kurang baik, siswa masih gaduh dan sebagian bingung untuk berbuat apa. Pada siklus berikutnya agar tidak terjadi hal yang sama maka guru menjelaskan tugas-tugas tiap anggota kelompok dan meningkatkan pengawasan kepada individu maupun kelompok.

e. Kreativitas, imajinasi, dan inisiatif siswa masih kurang karena mereka belum mampu mengembangkan ide yang dimiliki. Mereka merasa kesulitan dalam menemukan katakata untuk membuat cerita. Pada pertemuan berikutnya guru memberikan contoh cerita tertulis yang dibagikan pada tiap individu sebagai bahan untuk merangsang/memunculkan imajinasi, kreatifitas dan inisiatif siswa dalam membuat cerita. Selain itu guru meminta siswa untuk lebih mengembangkan Mind Mapping kerangka karangan cerita hasil pekerjaan siswa sehingga siswa lebih mudah merangkai kata dan menemukan alur cerita yang akan ditulisnya.

Sebagaimana yang dilakukan pada siklus I, dan II maka pada siklus III ini juga dilakukan analisis data yang mendalam terhadap deskripsi data yang dipaparkan di atas. Dari analisis lembar observasi aktivitas siswa terjadi perubahan keaktifan yang signifikan. Pada siklus I sebagian siswa belum berani dalam menyampaikan gagasannya. Pada siklus II ini sebagian besar siswa sudah berani untuk bertanya dan mengungkapkan pendapatnya. Demikian juga dalam mengerjakan tugas kelompok atau diskusi, secara keseluruhan siswa sudah memperlihatkan aktivitas yang sangat baik. Siswa juga menunjukkan peningkatan dalam kemampuan menulis cerita, secara keseluruhan siswa sudah mampu mengerjakan soal tes evaluasi secara optimal.

Vol. 9 No. 2, Juni 2017

Madrasah homepage: http://ejournal.uin-malang.ac.id/index.php/madrasah/index 
Selain itu keaktifan siswa di dalam pembelajaran pada siklus II ini meningkat terbukti dengan tingginya respon siswa terhadap pertanyaan yang diberikan guru, siswa menjawab pertanyaan guru dengan penuh semangat dan antusias. Siswa juga sudah bisa mengembangkan daya kreatifitas dan imajinasi mereka dengan baik, hal ini karena guru memberikan kebebasan untuk membuat kerangkanya. Hasilnya tulisan cerita siswa pun semakin baik. Keaktifan siswa yang meningkat secara signifikan tersebut terjadi karena kinerja guru yang semakin baik dari siklus I-III.

\section{Hubungan Antar Siklus}

Dari daftar perbandingan nilai kemampuan menulis cerita siswa kelas IV SDN Sumurgung di atas dapat disajikan dalam bentuk tabel 1.3 seperti berikut ini:

Tabel D.3 Data Distributif Frekuensi Perbandingan Nilai Menulis Cerita

\begin{tabular}{|ccccc|}
\hline \multirow{2}{*}{ No } & \multirow{2}{*}{ Interval Kelas } & \multicolumn{3}{c|}{ Frekuensi } \\
\cline { 2 - 5 } & & Siklus I & Siklus II & Siklus III \\
\hline 1 & $\leq 64$ & 8 & 6 & 2 \\
\hline 2 & $65-74$ & 7 & 0 & 1 \\
\hline 3 & $75-84$ & 8 & 12 & 9 \\
\hline 4 & $85-94$ & 0 & 5 & 10 \\
\hline 5 & $\geq 95$ & 0 & 0 & \\
\hline
\end{tabular}

Dari tabel distributif frekuensi perbandingan perolehan nilai menulis cerita melalui metode peta pikiran (Mind Mapping) tersebut, terlihat adanya peningkatan frekuensi nilai siswa di atas KKM yaitu 65 Jumlah siswa yang mendapatkan nilai di atas KKM meningkat dari siklus I, II dan Siklus II. Dari hasil perbandingan frekuensi nilai di atas dapat dibuat grafik perbandingan sebagai berikut ini:

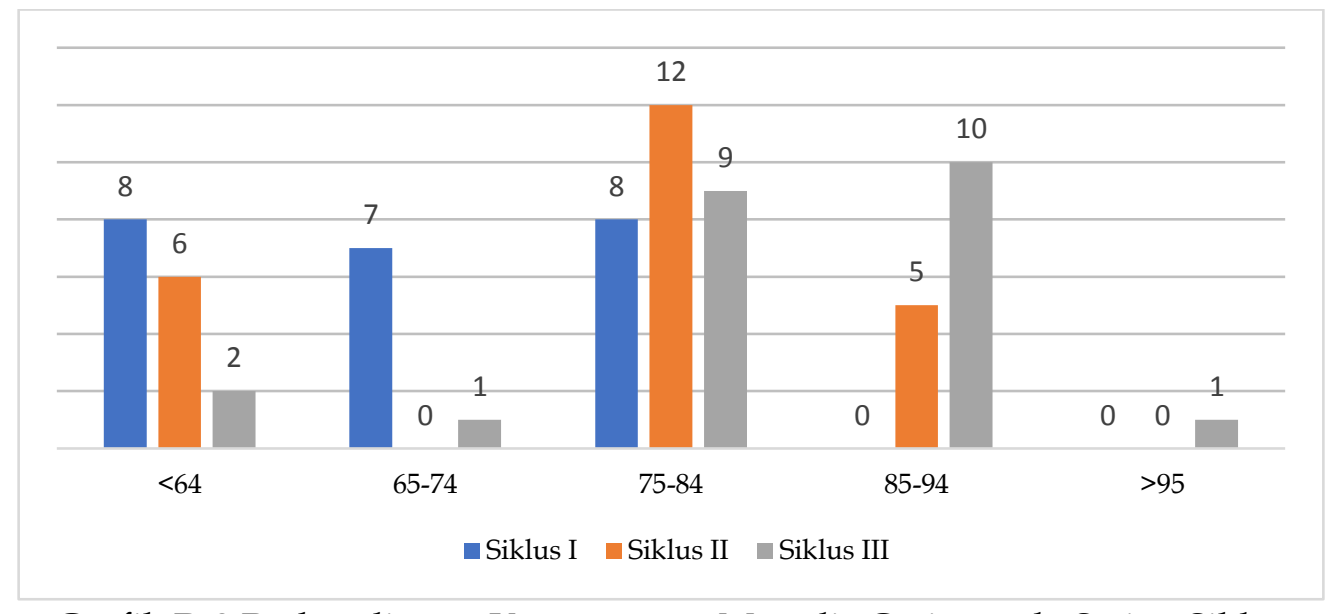

Grafik D.2 Perbandingan Kemampuan Menulis Cerita pada Setiap Siklus

Berdasarkan tabel dan grafik perbandingan perolehan nilai menulis cerita di atas dapat dilihat adanya hubungan antar siklus yaitu mengenai kemampuan menulis cerita yang semakin meningkat dari sebelum tindakan hingga sesudah tindakan. Peningkatan kemampuan menulis cerita tersebut dapat terjadi karena dilaksanakan pembelajaran menulis cerita melalui metode Mind Mapping yang semakin baik dari siklus ke siklus. Dari

Vol. 9 No. 2, Juni 2017

Madrasah homepage: http://ejournal.uin-malang.ac.id/index.php/madrasah/index 


\section{MADRASAH}

hasil observasi dan refleksi di tiap siklus dapat dijadikan pedoman untuk perbaikan pembelajaran berikutnya.

Hubungan peningkatan kemampuan menulis cerita antar siklus dapat dibuktikan melalui hasil yang dijabarkan berikut ini: pada siklus I siswa yang memperoleh nilai pada interval $\leq 64$ ada 8 siswa, siklus II ada 6 siswa dan siklus III ada 2 siswa yang memperoleh nilai pada kelas interval tersebut. Siswa yang memperoleh nilai pada kelas interval 65-74 pada siklus I ada 7 siswa, di siklus II tidak ada siswa dan siklus III ada 1 siswa yang memperoleh nilai pada interval tersebut. Sedangkan yang memperoleh nilai pada kelas interval nilai 75-84 pada siklus I ada 8 siswa, di siklus II menjadi 12 siswa dan di siklus III 9 siswa. Siswa yang memperoleh nilai pada interval kelas 85-94 siklus tidak ada siswa, siklus II ada 5 siswa dan III ada 10 siswa.

Lebih lanjut dijelaskan bahwa yang memperoleh nilai pada kelas interval nilai $\geq 95$ pada siklus I dan II tidak ada siswa yang memperoleh nilai pada kelas interval tersebut sedangkan di siklus III ada 1 siswa. Dengan demikian dapat disimpulkan bahwa nilai kemampuan menulis cerita siswa dapat ditingkatkan melalui metode Mind Mapping.

\section{E. SIMPULAN}

Dari hasil kegiatan pembelajaran yang telah dilakukan selama tiga siklus, dan berdasarkan seluruh pembahasan serta analisis yang telah dilakukan dapat disimpulkan sebagai berikut:

1. Pembelajaran dengan metode pembelajaran peta pikiran (Mind Mapping) memiliki dampak positif dalam meningkatkan prestasi belajar siswa yang ditandai dengan peningkatan ketuntasan belajar siswa dalam setiap siklus, yaitu: siklus I $(65,22 \%)$, siklus II $(73,91 \%)$, siklus III $(91,30 \%)$ dan nilai rata-rata kelas yaitu: siklus I $(63,87)$, siklus II $(74,35)$, dan siklus III $(80,43)$.

2. Penerapan metode pembelajaran peta pikiran (Mind Mapping) mempunyai pengaruh positif, yaitu dapat meningkatkan kemampuan menulis cerita dan motivasi belajar siswa yang ditunjukan dengan hasil tes formatif dan wawancara dengan beberapa siswa, rata-rata jawaban menyatakan bahwa siswa tertarik dan berminat dengan metode pembelajaran peta konsep (Mind Mapping) sehingga mereka menjadi termotivasi untuk belajar.

\section{REFERENSI}

Akhadiah, Sabarti dkk. (1988). Pembinaan Kemampuan Menulis Bahasa Indonesia. Jakarta: Erlangga

Arifin, Zainal. (2009). Evaluasi Pembelajaran Prinsip, Teknik, Prosedur. Bandung : PT Remaja Rosdakarya

Buzan, Tony. (2011). Buku Pintar Mind Map. Jakarta: Gramedia Pustaka Utama.

Dahar, R.W. (1989). Teori-teori Belajar. Jakarta: Erlangga.

Edward, Caroline. (2009). Mind Mapping untuk Anak Sehat dan Cerdas. Yogyakarata: Sakti. Guntur, Henry. (1994). Membaca Sebagai Suatu Keterampilan Berbahasa. Bandung: Angkasa H.J. Gino. (1999). Belajar dan Pembelajaran 1. Surakarta: Universitas Sebelas Maret. Iskandarwassid dan Dadang Sunendar. (2009). Strategi Pembelajaran Bahasa. Bandung: Remaja Rosdakarya.

Moh. Uzer Usman. (2008). Menjadi Guru Profesional. Bandung: PT Remaja Rosdakarya 
Sugiarti, Titik. (1997). Penelitian Tindakan Kelas. Makalah disampaikan pada Pelatihan Peningkatan Kualifikasi Guru S1 PGSD. Universitas Jember

Soedomo, A. Hadi. (2005). Pengelolaan Kelas. Surakarta: UNS Press

St.Y. Slamet. (2007). Dasar-Dasar Keterampilan Berbahasa Indonesia. Surakarta: Universitas Sebelas Maret Press.

Taruno, Bagus Legowo. (2009). Freemind Mind Mapping Software. Surabaya: Masmedia Buana Pustaka.

Trianto. (2010). Mendesain Model Pembelajaran Inovatif-Progresif: Konsep, Landasan, dan Implementasinya pada Kurikulum Tingkat Satuan Pendidikan (KTSP). Jakarta: Kencana Prenada Media Group.

Windura, Sutanto. (2008). Mind Map, Langkah Demi Langkah. Jakarta: Elex Media Komputindo.

Wiyanto, Asul. (2004). Terampil Menulis Paragraf. Jakarta: Grasindo. 